\title{
The Use of Charades Games in Teaching Vocabulary to the Junior High School Students
}

\author{
Fauzi Bafadal, Humaira, Nurmasitah \\ a bc University of Muhammadiyah Mataram, Indonesia, a fauzi.bafadal@gmail.com
}

\begin{tabular}{|c|c|}
\hline ARTICLE INFO & ABSTRACT \\
\hline $\begin{array}{l}\text { Article history: } \\
\text { Received } \\
\text { Revised } \\
\text { Accepted }\end{array}$ & $\begin{array}{l}\text { Vocabulary is knowledge of words and word meanings. To increase } \\
\text { the student's vocabulary, the writer chosen game. Game is an } \\
\text { alternative way to teach. One of the alternative games is charades } \\
\text { game. So, based on it the aim of this study is to investigate the effect } \\
\text { of charades game toward student's vocabulary. This study was } \\
\text { conduct at the first grade students of SMPN } 18 \text { Mataram in academic } \\
\text { year } 2017 / 2018 \text {. This study used quasi experimental design that is } \\
\text { used pre-test and post-test control group design. The population of } \\
\text { study involved } 40 \text { students from two classes SMPN } 18 \text { Mataram in } \\
\text { academic year } 2017 / 2018 \text {. The writer took all of the students as a } \\
\text { sample, they are } 20 \text { students belong to the experimental group and } 20 \\
\text { students in control group. In this study, the writer used vocabulary } \\
\text { test consist of } 20 \text { items multiple choice covered with indicator of } \\
\text { vocabulary consist of spelling, pronunciation and meaning. The result } \\
\text { of this study, the students could understand about spelling, } \\
\text { pronunciation and meaning and they could answer the test vocabulary } \\
\text { easily through charades game. In this data, pre-test and post-test as } \\
\text { the research technique of data collection, then followed by analyzing } \\
\text { the data using t-test formula. The level of significant is at } 0 \text {, 05\%, t- } \\
\text { test = 2,99 and t-table= } 2,02 \text {, Alternative Hypothesis (Ha) was } \\
\text { accepted and Null Hypothesis (Ho) was rejected. It means that there } \\
\text { was significant different between the students pre-test and post-test } \\
\text { scores. Thus, the writer concludes that charades game on the } \\
\text { student's vocabulary has effect. }\end{array}$ \\
\hline
\end{tabular}

\section{Introduction}

Vocabulary is one of the essential language components in studying English. It is necessary in the sense that words are the basic building blocks of language, the unit of meaning from which larger structures such as sentences, paragraphs and whole texts are formed (Read, $2000: 1$ ). If people have less vocabulary, they not only cannot understand others saying, but also cannot make sentences to transfer their messages to the other people.

Thus, they will understand English expressions if they have enough vocabularies. "If you spend most of your time studying grammar, your English will not improve very much. You will see most improvement, if you learn more words and expressions. You can say very little with grammar, but you can say almost anything with words!" (Thornburry; 2002: 13). So, vocabulary is an important thing to learn English without understands grammar deeply meanwhile sometimes the teachers still find out any problems in students vocabulary.

In the fact at SMPN 18 MATARAM there are several problems was faced, there are: The students" enthusiasm and active learning are still not visible, the students still lack on vocabulary, They still lack facilities to improve their English learning.

To cope with those problems and the poor of vocabulary mastery, there must be several solutions. One of the solutions is through game, especially charades game. Charadesgame is one of game that can use in teaching vocabulary. It will help teachers in teaching and learning English. According Kaduson and Schaefer (2003: 217), charades is an excellent to facilitate the emotional education of the children. It can be used as prevention for the emotional well-being of children experiencing emotional difficulties, or remediation for children who appear to be lagging in emotional development. Because this game requires the child to be in the center of attention for a 
few minutes, it is intrinsically motivating. Another definition is occur according to Nau (2000), charades is a game of pantomimes. One should have to act out a phrase without speaking, while the others try to guess what the phrase is. Similarly, Tate (2004) adds that charades is acting out words, actions, or feelings in a text. In addition, Glouberman (2003) says that Charades is a game using the face and the body to communicate.

The writer believes that the game can be the way to minimize the student's boredom in learning vocabulary. The writer used charades game because the game is practical and simple to be applied in class. The game is also suitable to teach English vocabulary for students at the first grades because this game can make the students in learning new words. This game can also build students selfconfidence because this game is played in groups. The writer expects that by using charades game, students can memorize new vocabularies easily and enjoy the learning.

There are several writers who have done research in the charades game, the first writer is Windy DyahIndiani 2013 entitled "the influence of charades game on the students' competence in English vocabulary at the fifth grade students of kepongpongan3 elementary school". Last writer is Bahresi Farqi Fazat, 2014 entitled "Charades game in teaching vocabulary to the seventh grade students of MTs Negeri Sewulan Dagangan Medium in Academic year 2013/2014".

This issue motivates the writer to conduct a research on the student's vocabulary achievement to the first grade students in SMPN 18 MATARAM in academic year 2017/2018.

\section{Method}

\section{A. Research Design}

The method that used in this research was Quasi Experimental with the Non equivalent Control Group Design. According to Nunan (1992) Quasi Experimental is giving pre-test and post-test, using control group and there is no determination of subject randomly. In this study, the writer was used quasi experimental because the writer believe quasi experimental helped the writer to investigated that charades game has effect in teaching vocabulary at the first grade students of SMPN 18 MATARAM. There are some procedures that used in this research as like the researcher divide the group into two group namely experimental group and control group first group call experimental group was treated by using Charades game, while second group call control group was not used charades game.

\section{B. Population and sample}

Population is object or subject which has quality and characteristic used by the writer to study then made the conclusion (Sugiyono, 2014: 80). The total of population in this study at the first grade students of SMPN 18 MATARAM in academic year 2017/2018 were 40 students which divided into two classes, they were VII A 20 students, VII B 20 students.

Setyosari (2015: 220) states that sample is a group of objects, people, events, and so on which is a representation of the whole. Simply Ary, Jacobs, and Sorensen (2010) A sample in a research study is the group on which information is obtained. Arikunto (2002:134) states that if the subject of population less than 100 , its better to take all of them.

Based on the statements above, in this research the writer was applied purposive sampling. This population is less than 100 people and in this research the writertook all of the students as a sample they were VII A 20 students as the experimental group and VII B 20 students as the control group

\section{Research instruments}

In this study, the writer used a test vocabulary as an instrument. In this study, the writer gave vocabulary test for the students before and after giving treatment. The test in the form at multiple choice consist of 20 items that covered with indicator of vocabulary consist of; pronunciation, spelling and meaning. The sources of instrument taken from the When English Rings a Bell book.Score is the result of work gives the figures obtained by adding up the numbers for each items in the correctly test while the value is a number (can also letter) which is the result of change score Sudijono (2007:309). The correct answer weights does not necessarily have a score of 1 but also can have $1 \frac{1}{2}, 2 \frac{1}{2}, 5$ and so on. In this research the writer gave score 5 if correct answer and gave 0 if incorrect. 


\section{Data Collection}

The writers collected the data from pre test and post test of the students score experimental group and control group. There are steps of collecting data as follows:

1. Pre-test

This is the first step in gathering the data,the writer gave the students pre test in the first meeting in the classroom. That pre test aimed to know underlying knowledge of the students in vocabulary. The kind test is multiple choices the topic is "things and animals" with 20 questions. The weight of each question of the test is 5 if correct and 0 is wrong. The student's correct answer and duration of the time is about 60 minutes.

\section{Treatment}

The treatment is presenting charades game for experimental class after the researcher give the students pre-test while in class control not teach by used charades game. The treatment of charades game is a technique for experimental class before the writers gave the students post-test. The writer came to the class with the students in order to know how far the students collected their vocabulary. The treatment is gave by the writers after pre-test and took value score with gave post-test.

\section{Post test}

The post-test is the last of meeting for knowing is charades game can usedor not inteaching vocabulary. The item test consists of 20 questions of multiple choices withthe topic "things and animals"when the weight of each question is 5 if the answer is correct and zero if the answer incorrect. The student's correct answer and duration of the time is about 60 minutes. The test is same as the one is given in pre test.

\section{E. Data Analysis}

The writers used experimental research that describes a quantitative degree. The data collected from the result of pre-test and post-test. In calculating the students mean score of experimental group and control group, the researcher used the following formula:

a. To find the students mean score of experimental and control group, used the following formula:

$$
\begin{aligned}
& M x=\sum \frac{x}{N} \\
& M y=\sum \frac{y}{N}
\end{aligned}
$$

Where:

$\mathrm{Mx}$ : the mean score of experimental group

My: the mean score of control group

$\mathrm{X}$ : the total score for experimental group

$Y$ : the total score for control group

$N$ : the number of sample

a. To find out the standard deviation of experimental group and control group. The formula of standard devotion as follow:

1. Find out the standard deviation of experimental group. The formula as follows:

$$
\sum x=\sum x^{2}-\frac{(x) 2}{N x}
$$

Where:

$\mathrm{X}$ :The students standard deviation for experimental

$\mathrm{N}$ : Number of sample

2. Find out the standard deviation of control group, the formula as follow: 


$$
\sum y=\sum y^{2} \frac{(y) 2}{N y}
$$

Where:

Y: the student's standard deviation for control group

$\mathrm{N}$ : the number of sample

c. The last in the testing the significance of two variables standard deviation by using the following formula:

$$
\mathrm{T}=\frac{M_{X}-M_{y}}{\sqrt{\left(\frac{\sum \mathrm{x}^{2}+\sum \mathrm{y}^{2}}{N_{X}-N_{y}-2}\right)-\left(\frac{1}{N_{X}}+\frac{1}{N_{y}}\right)}}
$$

Where:

My : mean score of control group

Mx : mean score of experimental group

$\mathrm{N}$ : total number of subject

The deviation of experimental group

$\mathrm{Y}$ : the deviation of control group

The degree of freedom:

df: $(\mathrm{Ne}+\mathrm{Nc}-2)$

df: degree of freedom

Ne: the number of experimental group

Nc: The number of control class

With the hypothesis statistic as follows:

If t-calculation> t-table: Ho rejected and Ha accepted

If $\mathrm{t}$-calculation< $\mathrm{t}$-table: Ho accepted and Ha rejected

(Arikunto, 2013: 321-326)

\section{Findings and Discussion}

\section{A. Data Findings}

In this chapter, the writer focus on the statistical analysis of data obtained from the pre-test and post-test of experimental and control group. The design was select two classes as experimental and control group. The total population were 40 students consisted of two classes that were class VI1 A 20 students, V1I B 20 students and the writer was took all of the students.

There are three steps the writer used on the technique of data collection:

The first is pre-test, the writer giving pre-test both of group. The aim of these steps, to know the students basic knowledge of vocabulary mastery with topic 'how many pet do you have' consist of 20 multiple choice before giving treatment

The Second is treatment; the aimed of this treatment is presented charades game after giving pretest.For experimental group were treated by charades game and control group were not treated by charades game.

And thirdly is post-test, that is the writer giving after pre-test and treatment the aim of post-test is to know the students value before and after giving treatment by charades. 
To get the result of three steps above the writer showed the result of student's pre-test and posttest below:

\section{A. Computation of mean score}

The student's individual score for both experimental and control groups can be seen on the following tables:

Table 4.1 The Deviation Scores of Experimental Group

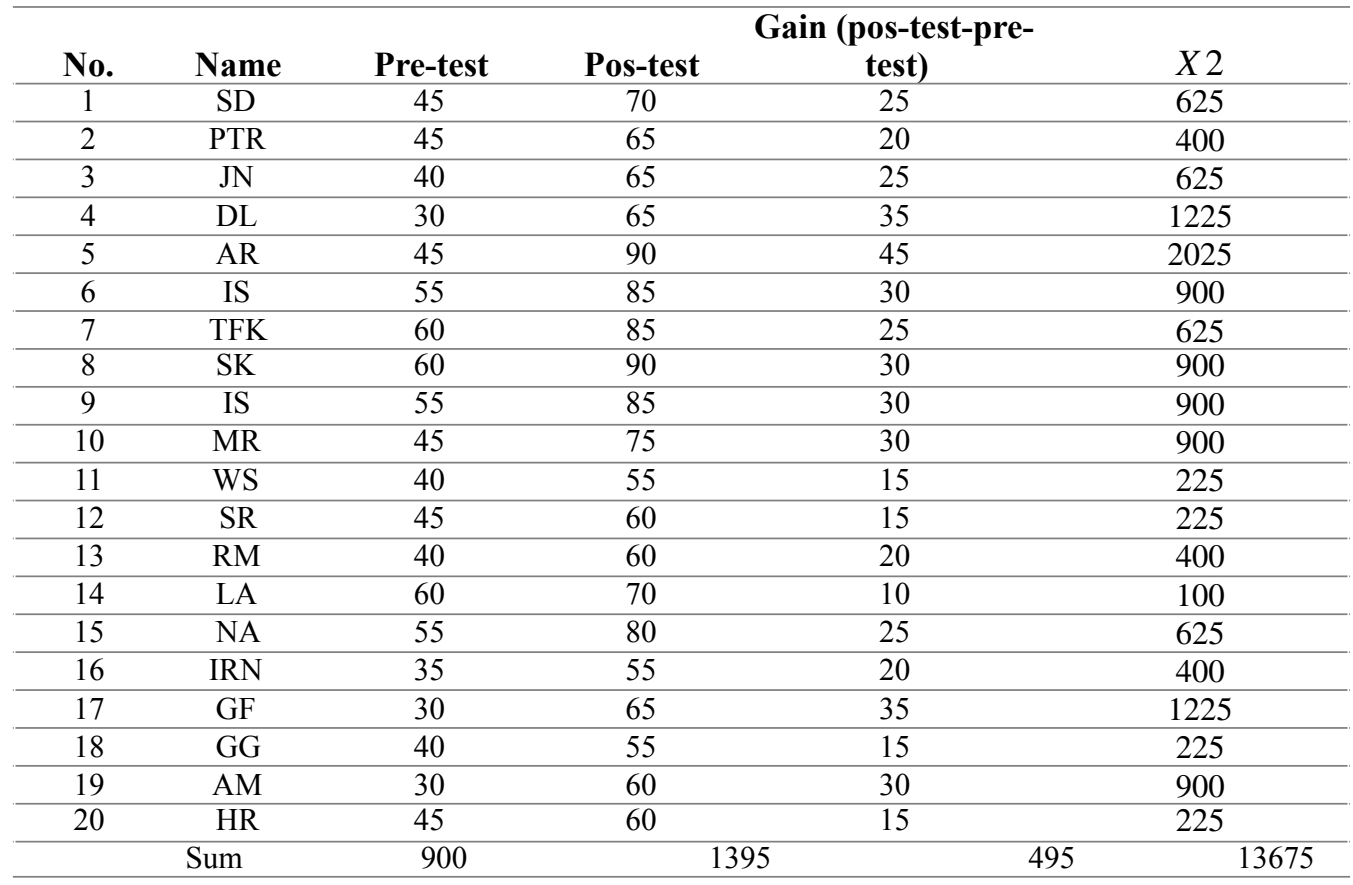

To get mean score of two groups in this investigation, the writer applied the following formula:

$$
\begin{aligned}
& M_{x}=\sum \frac{x}{n} \\
& M_{x}=\sum \frac{x}{n} \\
& M_{x}=\sum \frac{495}{20} \\
& M_{x}=24,75
\end{aligned}
$$

From the table, to get mean score of two groups in these investigations, the researcher applied the following formula:

$$
\begin{aligned}
& M_{y}=\sum \frac{y}{n} \\
& M_{y}=\sum \frac{y}{n} \\
& M_{y}=\sum \frac{300}{20} \\
& M_{y}=15.00
\end{aligned}
$$




\section{B. Computation of standard deviation}

For the calculated the students' standard deviation of two groups, the writer following formula:

a. The mean deviation of experimental group

$$
\begin{aligned}
& \sum x=\sum x^{2}-\frac{x^{2}}{n} \\
& \sum x=13675-\frac{459^{2}}{20} \\
& \sum x=13675-\frac{245025}{20} \\
& \sum x=13675-12251,25 \\
& \sum x=1423,75
\end{aligned}
$$

b. The mean deviation of control group

$$
\begin{aligned}
& \sum y=\sum y^{2}-\frac{y^{2}}{n} \\
& \sum y=7100-\frac{300^{2}}{20} \\
& \sum y=7100-\frac{90000}{20} \\
& \sum y=7100-4500 \\
& \sum y=2600
\end{aligned}
$$

\section{Computation of t-test}

$$
\begin{aligned}
& t=\frac{M_{x}+M_{y}}{\sqrt{\left(\frac{\sum x+\sum y}{n_{x}+n_{y}-2}\right)\left(\frac{1}{n_{x}}+\frac{1}{n_{y}}\right)}} \\
& t=\frac{24^{\prime} 75-15.00}{\sqrt{\left(\frac{1423,75-2600}{20+20-2}\right)\left(\frac{1}{20}+\frac{1}{20}\right)}} \\
& t=\frac{9,75}{\sqrt{\left(\frac{1423,75+2600}{38}\right)(0.1)}} \\
& t=\frac{9,75}{\sqrt{\left(\frac{4023,75}{38}\right)(0.1)}} \\
& t=\frac{9,75}{\sqrt{(105,89)(0.1)}} \\
& t=\frac{9,75}{\sqrt{10,59}}
\end{aligned}
$$




$$
\begin{aligned}
& t=\frac{9,75}{3,25} \\
& t=2,99
\end{aligned}
$$

Based on the data above, it showed that the students post-test higher than pre-test with score $(900 / 20)=45$ and $(1395 / 20)=69,75$ It means that there was significant difference between before and after treatment students were taught by charades game.

In hypothesis the writer used t-test formula. The level of significant is $0,05 \%$, t-test $=2,99$ and $t$ table $=2,02$. From analysis, the Alternative Hypothesis (Ha) was accepted and Null Hypothesis (Ho) was rejected. It means that there was significant different between the students pre-test and post-test scores. Thus, the writer concludes that charades game at the first grade students of SMPN 18 Mataram has effect on the student's vocabulary.

\section{B. Discussion}

This study aimed to investigation, charades game has effect or not in teaching vocabulary at the first grade of SMPN 18 Mataram. In this research, the writer used two groups as a sample that were class VI1 A as an experimental group and VII B as control group, consist of 40 students they were VII A 20 students and V1I B 20 students.

The result of this study, students could understand about spelling, pronunciation and meaning. In the fact, before students treated by charades game the students could not understand about spelling, pronunciation and meaning for example in spelling the students difficult how to spell 'table' after treated by charades game the students could understand the spelling of 'table' is 'ti,ei,bi,ei and i' after that in pronunciation, the students was could not understand about how to say 'book' in their mind 'book' is 'book' but actually the pronunciation of 'book' is 'buk' and the then about meaning, the student still lack the meaning of words for example when the teacher asked some words like 'a teacher' the students could not understand because the student didn't know about the meaning of 'teacher' but after the writer treated by charades the students could understand because charades game is a game how to act out words without speaking and have to used pantomime and expression in order to the students could get the meaning and memorize about the actor or actress act out in front of the class. Beside spelling, pronunciation and meaning through charades game the students was in centre of attention for a few minutes and charades game also made classroom more fun and not bored like when the actor or actress act out some words in the classroom all of the students thinking hard to guess what the meaning of that words, the students were compete for the best one of them and the class was enthusiasm, having fun and not bored.

Based on the result, the writer can conclude that used of charades game has effect in teaching vocabulary at the first grade of SMPN 18 Mataram in academic year 2017/2018.

\section{Conclusion}

Based on the research, the writer can conclude that "Charades Game in Teaching Vocabulary" has effect because the students could understand about spieling, pronunciation, and meaning then answer the test vocabulary easily. Based on the data analysis the writer concludes score of experimental group higher than control group. The result of computation of t-test was 2,99 and ttable was 2,02. It means that t-test 2,99 is higher than $\mathrm{t}$-table 2,99>2,02 was significantly different. It means after the students treated by charades game at the first grade students of SMPN 18 Mataram has effect because charades game could increase their vocabulary

\section{References}

1. Bahresi Farqi Fazat. 2014 with entitled "Charades game in teaching vocabulary to the seventh grade students of MTsnSewulanDagangan Medium in Academic year 2013/2014

2. Cameron, Lynne. 2001. Teaching Languages to Young Learners. New York: Cambridge University Press

3. Carrier, Michael and the Centre for British Teacher. 1984. Take 5. Games and activities for the learner, Harahap limited Ltd.

4. Creswell, John W. 2009. Research Design 3rd edition: Qualitative, Quantitative, and Mixed Methods Approaches. USA: SAGE Publicatio ns, Inc.Ramelan, H. 1994. Teaching and Learning Language. Semarang: IKIP Press. 
5. Dayton, Tian. 1990. Drama Games. New York: Health Communications

6. Ellery, Valerie. 2009. Creating Strategic Readers. New York: Library of Congress Cataloging-inPublication Data

7. Gairns, Ruth and Redman Stuart. 2003. Working With Words: A Guide to Teaching and Learning Vocabulary. New York: Cambridge University Press

8. Harmer, J. 2001.The Practice of English Language Teaching. Cambridge: Longman.

9. Himmele, Persida\& William Himmele. 2011. Total Participation Techniques. Alexandria: Library of Congres Cataloging-in- Pablication Data

10. Kaduson, Heidi Gerard \& Schaefer, Charles E. 2003. 101 Favorite Play TerapyTechniques.Estover: Library of Congress Cataloging in-Publication Data

11. Kaduson, Heidi Gerard \& Schaefer, Charles E. 2003. 101 Favorite Play TerapyTechniques.Estover: Library of Congress Cataloging in-Publication Data

12. Kinds of game in teaching vocabulary.(https://busyteachers.org)

13. Koshy, Valsha. 2005. Action Research for Improving Practice. London: Sage Publication

14. Layne, Marty. 2007. Learning At Home. Canada: Sea Change Publication

15. Linse, Caroline T. 2005. Practical English Language Teaching Young Learners. New York: McGraw-Hill ESL/ELT

16. Nation, 2001.learning vocabulary in another language. New York: Cambridge University Press.

17. Nation, 2001.Productive vocabulary and receptive vocabulary. Bandung: penerbit.

18. Nation, I. S. P. 2001.Learning Vocabulary in Another Language. New York: Cambridge University Press

19. Nau, Dana. 2000. Rules for the game of charades. Retrieved on June 12 th 2015, fromhttp:// www.readingrockets.org/article.php?ID=472

20. Nunan, D.2003. Practical English language teaching. New York. NY: McGrawhill/Conteporary.

21. Rafinggi, Dhika Lomita. .Teaching Vocabulary by Using Charades Technique for Young Learners.STKIP PGRI West Sumatra.

22. Richards, Jack C \& Willy A. Renandya. 2002. Methodology in Language Teaching: An Anthology of Current Practice. New York: Cambridge University Press

23. Sugiyono. 2014. ProsedurepenelitianSuatuPendekatanPraktik. Jakarta: RinekaCipta.

24. Suyanto, Kasihani K. E. 2007. English for Young Children. Jakarta: PT BumiAksara

25. Thornbury, Scott. 2002. How to Teach Vocabulary. London: Longman 